\title{
The Hydra of Madagascar (Cnidaria: Hydrozoa)
}

\author{
R.D. Campbell ${ }^{1}$
}

Keywords : Hydridae, Hydra, freshwater, taxonomy, Madagascar.

Madagascar has been isolated from other land for about 100 million years. Thus the hydra of the island have been evolving independently of the hydra on the continents during the Tertiary geological period. On the northern continents the species of hydra cluster into four groups. Three species were found in a search of about 100 sites across Madagascar. These species represent two, and perhaps three, of the four groups of species that are found on the northern continents. A green hydra found throughout the island is similar to the European Hydra viridissima. One type of brown hydra, $H$. madagascarensis n.sp., has characters intermediate between those of the vulgaris and braueri groups of continental brown hydra. The third species, unnamed in this paper, belongs to the vulgaris group. One continental group of hydra, the oligactis group, is not represented on Madagascar. The hydra that occur in Madagascar are very similar to some on the continents, indicating that these animals evolve exceedingly slowly.

\section{L'hydre de Madagascar (Cnidaria : Hydrozoa)}

Mots-clés : Hydridae, Hydra, eau douce, taxonomie, Madagascar.

Il y a environ 100 millions d'années que l'île de Madagascar s'est séparée du continent africain. De ce fait les hydres de l'île ont évolué indépendemment des hydres du continent africain et des continents de l'hémisphère boréal. Sur les continents de l'hémisphère boréal les hydres sont réparties en quatre groupes. Au cours des travaux de recherche, une centaine d'endroits furent étudiés dans les lacs, mares et différents cours d'eau de l'île, et trois espèces d'hydres furent ainsi trouvées. Une hydre verte présente dans chaque région de l'île est semblable à l'hydre européenne Hydra viridissima. Une autre espèce locale, $H$. madagascarensis n.sp., a des caractères intermédiaires entre les hydres brunes continentales appartenant au groupe vulgaris et au groupe braueri. Une troisième espèce - sans nom dans ce compte-rendu - appartient au groupe vulgaris. Le groupe d'hydre oligactis présent dans l'hémisphère Nord semble ne pas être présent à Madagascar. Les hydres trouvées à Madagascar sont très semblables à celles présentes sur les continents. Ce fait indiquerait que ces animaux évoluent très lentement.

\section{Introduction}

Hydra are freshwater polyps found on all the continents except Antarctica. They are also found on continental islands (islands that were once connected to continents) such as Japan and Greenland (Schulze 1927) but are apparently absent from oceanic islands such as Hawaii and Tahiti (Hickson 1930, Mumford 1940a). This suggests that hydra cannot disperse across oceans, and so they must have been spread over the landmass of Pangea before it broke up into continents. In the absence of a fossil record of these soft ani-

\footnotetext{
1. Department of Developmental and Cell Biology, University of California, Irvine, CA 92697 USA.

E-mail: rcampbel@uci.edu
}

mals, the zoogeography of hydra might provide the best clues about their evolution.

Madagascar was one of the first land areas to separate from Gondwanaland, about 100 million years ago. Since that time Madagascar has remained separated from the East coast of Africa by the Mozambique Channel. The hydra fauna of the island thus offers a glimpse of the early evolution of hydra that is independent from that of the continental faunas.

The modern systematics of hydra were set out by Schulze (1917) based largely on the European fauna. The several dozen of described species fall into four species groups (Campbell 1987) and these have been considered cosmopolitan. However hydra have scarcely been sampled from the southern hemisphere so it is not known if southern species fit into these same groups. 
The hydra of Madagascar are unstudied. The only mention of the existence of hydra on the island is a statement by Paulian (1961) that hydra have «been seen» on the island. Thus I sampled and studied freshwater polyps in Madagascar to further our understanding of the zoogeography of hydra.

\section{Materials and methods}

Hydra were collected during the months of May and June 1995 and July 1996. About 100 ponds, lakes, streams and rivers widely spread over the island were sampled by peering into the water and examining likely substrata : undersides and stems of water lily leaves ; surfaces of other aquatic plants and plant material hanging into the water ; and the undersurfaces of sticks and stones. Examinations lasted between 20 minutes and 4 hours at a site, and were judged sufficient to determine the likelihood of hydra being present.

Several polyps from each successful collection were brought into the laboratory and studied under further culture for up to 2 years. They were grown in Arrowhead Drinking Water $\left(1.7 \mathrm{mM} \mathrm{Cl}^{-}, 0.6 \mathrm{mM} \mathrm{HCO}_{3}^{-}\right.$, $0.2 \mathrm{mM} \mathrm{Ca}^{++}, 0.05 \mathrm{mM} \mathrm{Mg}^{++}, 0.5 \mathrm{mM} \mathrm{Na}^{+}, \mathrm{pH} \mathrm{7.8)} \mathrm{in}$ small petri dishes and fed freshly-hatched nauplii of Artemia salina daily.

Laboratory culture is essential for the taxonomic work on hydra for several reasons. Hydra take on diverse forms in natural settings due to local feeding and environmental conditions ; consistency in morphology only appears during culturing in which feeding and other conditions are defined and constant. Also, gonads and the embryos' thecae provide essential taxonomic characters and these are generally not present in freshly collected material. Extended culturing under a variety of conditions is often required before hydra can be induced to undergo sexual reproduction. Finally, most taxonomic work must be carried out with living material because the nematocysts and typical morphology change during fixation.

\section{Taxonomic account}

Three species were found in Madagascar.

\subsection{Hydra viridissima Pallas 1766}

Green hydra fitting the description of the European green hydra are the most widespread and abundant hydra in Madagascar. Freshly collected polyps were $0.5-2 \mathrm{~mm}$ in length and rarely budding. In culture they have the following characters. Polyps fed two artemia nauplii per day are 6 to $10 \mathrm{~mm}$ in column length when appearing relaxed. They usually have 6 to 8 tentacles, which are one quarter to one times the length of the body column. As individual polyps grow older and increase in size, the stalk grows and eventually becomes the size of the upper portion of the column and sometimes larger. Hydra fed two artemia daily carry an average of 1.4 developing buds simultaneously and produce about 1 bud per polyp per day.

The nematocysts (Fig. 1B-E) were found to have the following sizes: stenoteles, $9.3 \pm 0.6 \mu \mathrm{m}(\mathrm{n}=50)$; holotrichous isorhizas, $10.0 \pm 0.5 \mu \mathrm{m}(\mathrm{n}=40)$; atrichous isorhizas, $5.4 \pm 0.5 \mu \mathrm{m}(\mathrm{n}=50)$; and desmonemes, $4.9 \pm 0.4 \mu \mathrm{m}(n=50)$. The forms and sizes of the nematocysts are in agreement with those of the European green hydra (Semal-van Gansen, 1954 ; McAuley, 1984 ; Holstein, 1995).

The green hydra are protandric hermaphrodites. Occasional male specimens were collected but ovaries were not seen in the wild. In the laboratory some polyps formed gonads at unpredictable times, especially in dense cultures ; generally a culture of 500-1000 hydra would contain 5-25 sexual hydra for about two weeks during several months of culturing. Induction of sexuality in individual polyps was achieved by growing 5 hydra in a $25 \mathrm{~mm}$ diameter petri dish (newly detached buds being discarded daily) and feeding each polyp two artemia each day. Two or three small testes usually formed beneath the tentacles within a week and later one or two ovaries formed successively in the budding zone which usually stopped producing buds. The embryotheca matches the description for the European green hydra in that it consists of numerous concentric layers marked off into polygonal plates (Fig. 2). The theca contains an extra chamber in the side adjacent to the parental column (Fig. 2 arrowheads). A similar chamber has been noted in English green hydra (Grayson $1971: 437$ ) and a larger secondary chamber provides the diagnostic character for the North American $H$. hadleyi Forrest 1959. Sizes with standard deviations of 16 embryothecae were as follows : diameter of entire embryotheca, $419 \mu \mathrm{m}( \pm 38 \mu \mathrm{m})$; and diameter of the enclosed embryo, $307 \mu \mathrm{m}( \pm 75 \mu \mathrm{m})$. The width of the tiles on the surface of the theca is approximately $30 \mu \mathrm{m}$ and variable. Eggs and young embryos appeared white but polyps usually turned green within a few days of hatching. Most thecae had algae adherent to the outer surface of the embryotheca as reported for North American green hydra (Thorington et al. 1979). Many embryos were viable and several generations of sexual reproduction were produced in the laboratory.

These hydra are phototactic and often crowd into one area within a culture dish. 


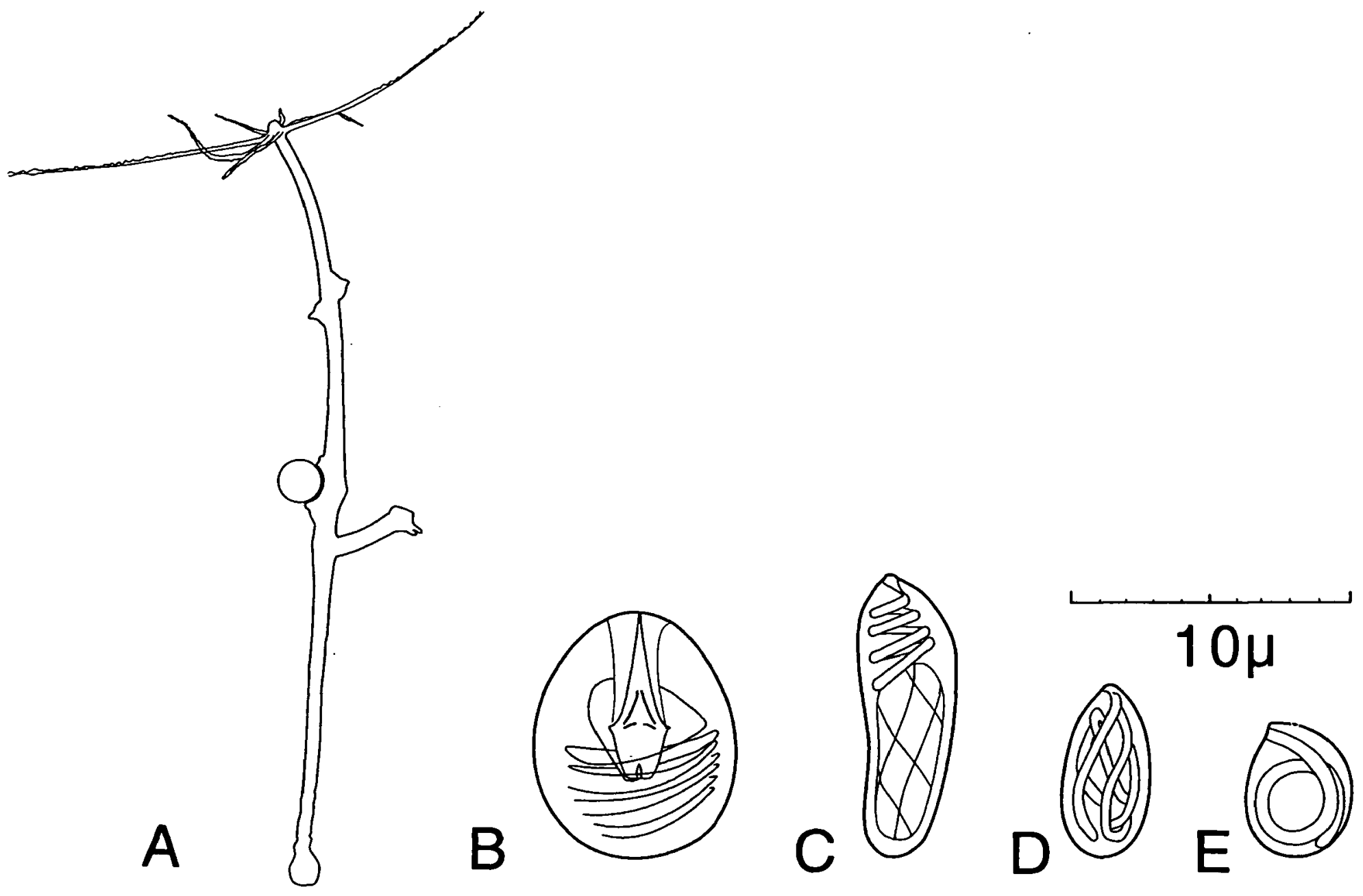

Fig. 1. Hydra viridissima Pallas 1766 from Madagascar, in laboratory culture. A : hermaphroditic polyp with an extruded egg. Length of column : $5 \mathrm{~mm}$. B-E : stenotele, holotrichous isorhiza, atrichous isorhiza and desmoneme nematocysts, respectively.

Fig. 1. Hydra viridissima Pallas 1766, venant de Madagascar, cultivée en laboratoire. A : polype hermaphrodite avec un oeuf saillant. B-E : nématocyste sténotèle, isorhize holotriche, isorhize atriche et desmonème.

H. viridissima is the most widespread and abundant hydra of Madagascar. It was found throughout the island (Fig. 3A) and in every habitat where hydra were found, from small stagnant ponds to small cascading mountain streams to large lakes and rivers. The hydra may be perched on any substratum in the water except that in cascading streams they were found only in slower pools on the undersides of wood and stones resting on the substratum. In a few places they were found on almost all plants and sticks but generally it would take 5-15 minutes of inspection to find one or two.

Localities where $H$. viridissima were found (Fig. 3A) : $1 \mathrm{~km} \mathrm{~S}$ Andasibe, in a shallow woodland pond ; $40 \mathrm{~km}$ E Antananarivo (1 km W of Mantsoa reservoir) in Lake Congrèves ; $20 \mathrm{~km} \mathrm{NE} \mathrm{Morondava} \mathrm{in} \mathrm{a} \mathrm{small}$ lake ; $8 \mathrm{~km} \mathrm{NW}$ Antsirabe along the E shore of Lake Andraikiba ; $3 \mathrm{~km} \mathrm{~S}$ Ampefy in Lake Mahlatrontoro ; $15 \mathrm{~km}$ SW Antsirabe in Lac Tritriva; $30 \mathrm{~km} \mathrm{~N} \mathrm{Ambo-}$ sitra in a rice paddy about $100 \mathrm{~m} \mathrm{~S}$ of Ilaka ; $33 \mathrm{~km} \mathrm{~S}$ Ambositra in a pond $W$ of route 7 and in a rice paddy $\mathrm{E}$ of the route ; $10 \mathrm{~km} \mathrm{~W} \mathrm{Ambatolampy} \mathrm{(ca} 40 \mathrm{~km} \mathrm{~S}$.
Antananarivo) in Lac Froid in Manjakalompo Forest/Pisciculture Reserve at the mouth of the exit stream ; $10 \mathrm{~km}$ E Maevatanana in Bonakely River at the crossing of route $4 ; 75 \mathrm{~km} \mathrm{~S}$ Antsiranana at the exit stream at the SE end of Lac Antanavo (= Lac Sacré) ; $30 \mathrm{~km}$ SW Antsiranana, Montagne d'Ambre Park, in Lac Vert and in the canal $S$ of the campground parking lot ; $6 \mathrm{~km} \mathrm{~S}$ Ambanja in a rice paddy ; $16 \mathrm{~km} \mathrm{E} \mathrm{Antso-}$ hihy in a grassland pond along route $6 ; 26 \mathrm{~km} \mathrm{~S}$ Antsohihy along route 6 on a rock dike in the lake ; $43 \mathrm{~km}$ $\mathrm{N}$ Mapinkony in a creek at the crossing of route 6 ; $9 \mathrm{~km} \mathrm{~S}$ Mahajanga in a small pond ; $79 \mathrm{~km} \mathrm{~S} \mathrm{Maha-}$ janga in a pond crossed by the road ; $53 \mathrm{~km} \mathrm{~S}$ Ambondromomy in the river at route $4 ; 105 \mathrm{~km} \mathrm{E}$ Sakaraha in a pond between bournes 690 and $691 ; 5 \mathrm{~km} \mathrm{~W}$ Ihosy in a cascading stream ; $31 \mathrm{~km}$ E Ihosy in a small river crossing route $7 ; 23$ and $27 \mathrm{~km} \mathrm{~W}$ Ambalavao in streams ; $40 \mathrm{~km} \mathrm{~W}$ Ambalavao along route 7 in Lomandao River midway between the two dams ; $9 \mathrm{~km} \mathrm{~S}$ Ambohimahasoa in a woodland lake; $32 \mathrm{~km} \mathrm{~N} \mathrm{Ambo-}$ himahasoa in a brook ; $68 \mathrm{~km} \mathrm{NW}$ Antananarivo along 


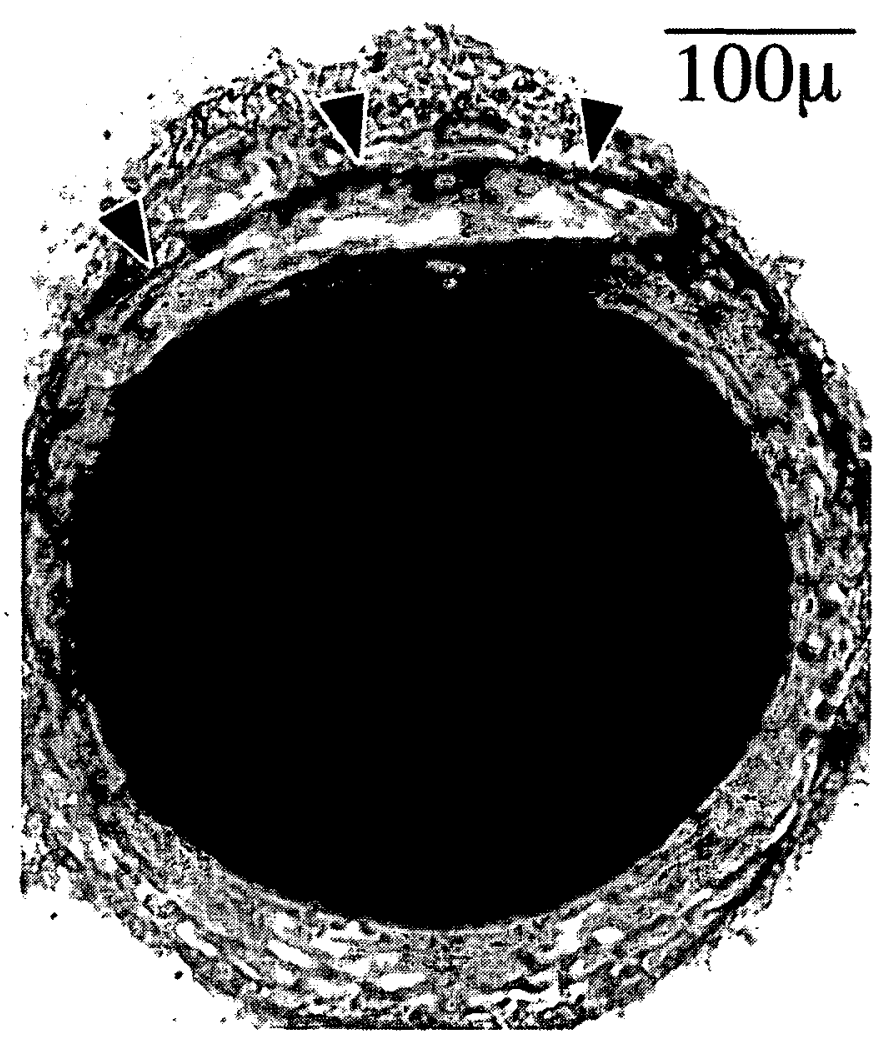

Fig. 2. Embryotheca of Hydra viridissima of Madagascar. The embryo proper (dark center) is surrounded with concentric lamellae of chitin which at the surface are marked off into slightly convex plates (visible at the bottom of the photograph). At the end closest to the parental column (top of photograph) the lamellae enclose an empty chamber (three arrowheads). The chamber varies in size from one theca to the next and is usually smaller than shown here.

Fig. 2. Embryothèque de Hydra viridissima de Madagascar. L'embryon (centre foncé) est entouré de lamelles concentriques qui forment à la surface des plaques légèrement convexes (visible à la base de la photographie). A l'extrémité la plus proche de la colonne parentale (en haut de la photographie) les lamelles forment une chambre (3 flèches). La taille de la chambre varie d'une thèque à l'autre ; celle-ci est plutôt grande.

route in a pond and also in a stream $0.5 \mathrm{~km}$ to the $\mathrm{NW}$; $77 \mathrm{~km} \mathrm{NW}$ Antananarivo in the outflow from the large reservoir ; $90 \mathrm{~km} \mathrm{NW}$ Antananarivo in the reservoir on the SW side of road.

Specimens are deposited as catalog \# 100078-79 in the United States National Museum of Natural History, Washington DC.

\subsection{Hydra madagascarensis n.sp.}

\subsubsection{Body form (Figs. 4A,B)}

Freshly collected polyps were between 0.5 and $1.5 \mathrm{~mm}$ in length, occasionally as long as $3 \mathrm{~mm}$. Colors of collected hydra included white, brown, orange and greenish. Sizes of polyps in the laboratory vary with the level of food. Polyps fed four artemia per day elongate to lengths of 4.5 to $6 \mathrm{~mm}$; polyps fed two artemia per day have lengths of 3 to $5 \mathrm{~mm}$. These measurements refer to hydra at rest, similar to their states in Figs. 4A-B, but the figured hydra were detached from the dish, a condition that stimulates hydra to elongate more. Long after feeding they sometimes become very thin and long, as do all hydra. During occasional contractions the polyps shorten to about $1 \mathrm{~mm}$ in length. The tentacles range from $1 / 3$ to 1 times the body length. Buds are borne spirally when there are three on the column ; when only two buds are present on the column they are opposite. The column beneath the buds is narrower and less colored, particularly in well-fed polyps, but not so conspicuously as to be called a stalk. Immediately after ingestion of prey this lower column becomes long, straight and slender.

\subsubsection{Nematocysts}

The nematocysts have the following ranges in lengths : stenoteles, 9-19 $\mu \mathrm{m}$; holotrichous isorhizas : 9-12 $\mu \mathrm{m}$; atrichous isorhizas : $7-9 \mu \mathrm{m}$; and desmonemes : 5-7 $\mu \mathrm{m}$. The distributions of these lengths are shown in Fig. 5. Most of the stenoteles are near the long end of a broad, unimodal distribution. The other types of nematocysts have narrow ranges in length. The most distinctive feature of this species is the holotrichous isorhiza nematocyst (Fig. 4D). It appears swollen and is about half as wide as long. The proximal transverse loops of the tubule are loosely coiled and sometimes irregular. The pattern of coiling is variable (Figs. 6C,F-J). 


\section{H. viridissima $\quad H$. madagascarensis $\quad H . s p . \quad$ study sites}

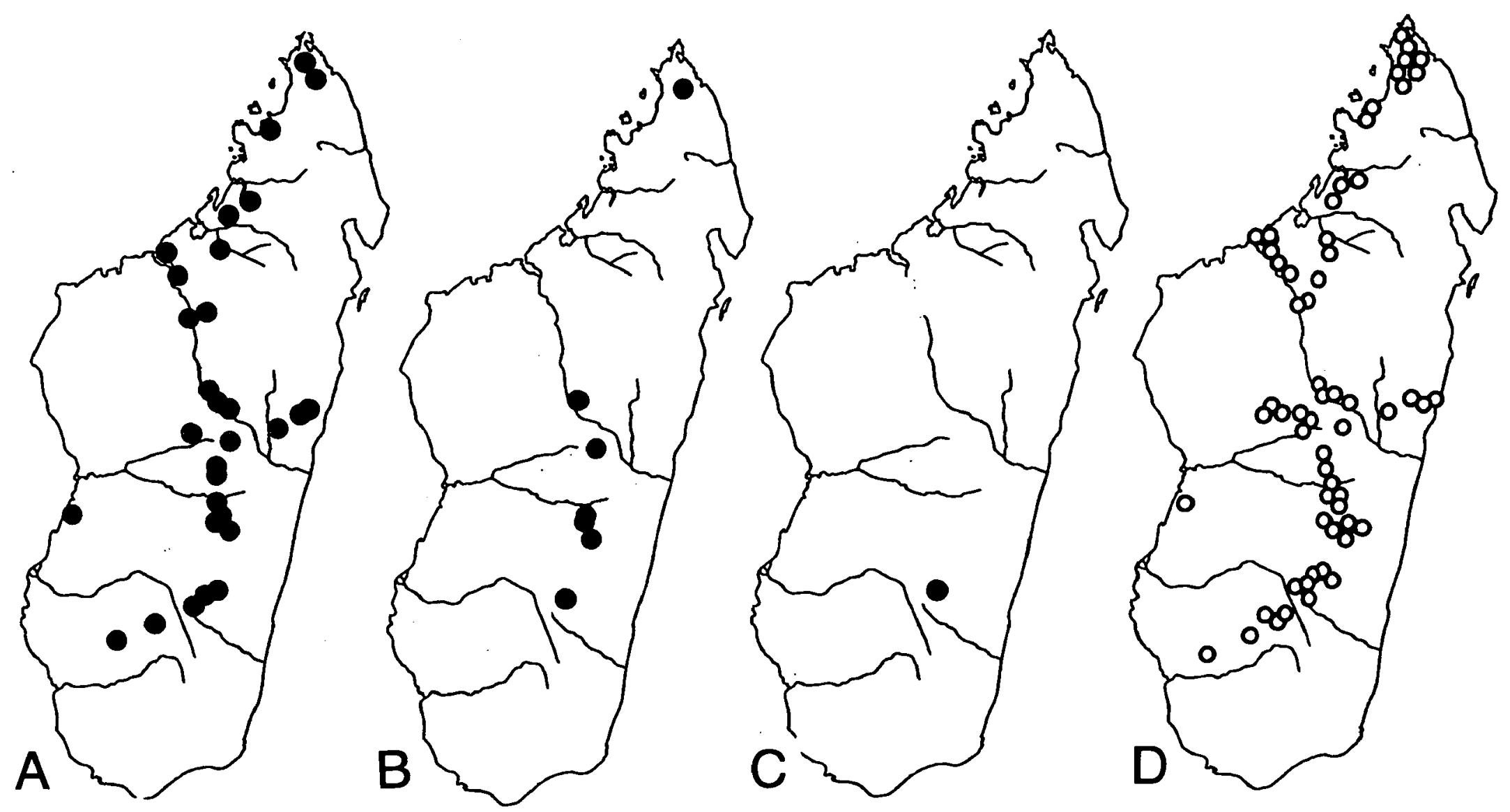

Fig. 3. Study sites. A-C : localities where hydra were found. D : all localities studied. Each symbol represents one or several nearby sites. The island is about $1500 \mathrm{~km}$ long.

Fig. 3. Les sites de recherche. (A-C) : Sites où des hydres furent trouvées. (D) : Tous les sites étudiés.

\subsubsection{Sexual reproduction}

This species is protandric hermaphroditic. In well-fed cultures all polyps older than 10 days develop testes. These are variable in size, shape and distribution, from tiny hemispherical structures in weakly developed individuals through massive testes that cover large regions of the body column. Even the largest testes are narrow in radial aspect. Typically (Fig. 4A) the testes are located within the upper half of the column and somewhat smaller in diameter than the column. Most testes are broadly triangular and the apex is slightly constricted, suggesting weak development of a nipple.

Ovaries develop near the budding zone (Fig. 4B), normally after budding has ceased. Usually one egg is produced at a time. Polyps form ovaries at unpredictable times in mass culture. Tentacles on hermaphroditic polyps are about $1 / 3$ the length of the column. Polyps grown individually and fed constant numbers of artemia daily usually develop ovaries within a few weeks.

The early embryogenesis is as described for the European $H$. vulgaris Pallas 1766 (Holstein 1995). The embryo cleaves and an embryotheca is formed while the embryo is attached to the mother. It is dropped free of the column after 3-4 days. Thecae are typically armed with strong spines (Fig. 4G center), but the degree of spination is variable and one quarter of the embryothecae have no spines at all. They sometimes have chitinous blisters (Fig. 4G left) in place of spines, either in a part of the theca or throughout. Sometimes spines are sparse and tiny (Fig. 4G right). The lengths of the spines vary from one theca to the next, and even within one embryo the spines may vary in length from one side to the other. Measurements on 37 thecae showed the following average sizes : external diameter of theca : $467 \mu \mathrm{m}$; length of spines : $29 \mu \mathrm{m}$; thickness of concentric chitinous layers under the spines : $20 \mu \mathrm{m}$; and diameter of cellular embryo : $357 \mu \mathrm{m}$.

Individual polyps can fertilize their own eggs, and about $50 \%$ of self-fertilized eggs (as well as cross-fertilized eggs) hatch after periods of 4-9 months. Most hatched hydra are viable and appear normal. 

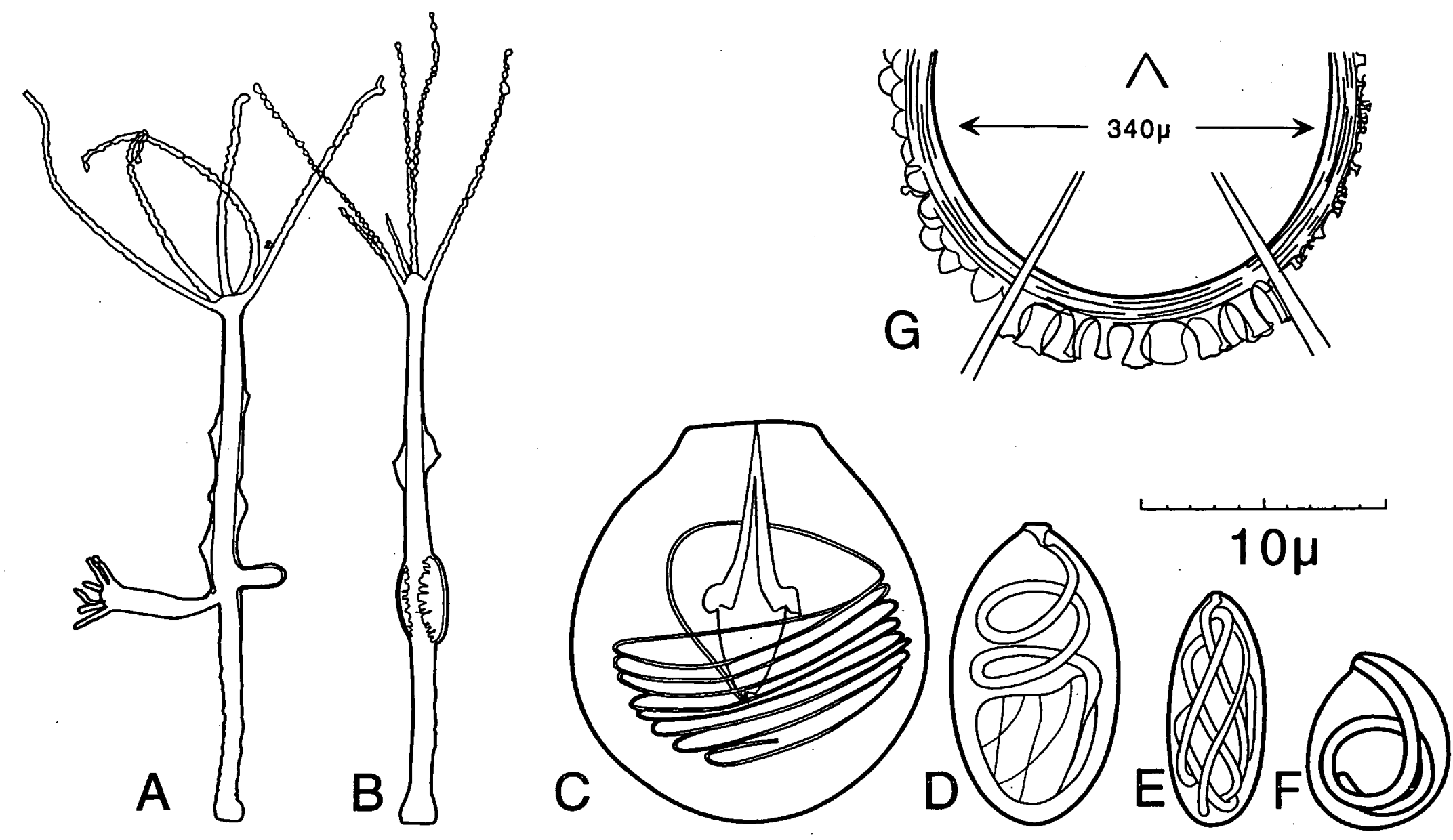

Fig. 4. Hydra madagascarensis n.sp. cultured in the laboratory and fed three artemia each day. A : male polyp, similar in appearance to asexual polyps. The polyp's column is $6.5 \mathrm{~mm}$ long. B : hermaphroditic polyp, $7.1 \mathrm{~mm}$ long. C-F : stenotele, holotrichous isorhiza, atrichous isorhiza and desmoneme nematocysts. $G$ : three types of decoration on the embryothecae: chitinous blisters (left), moderately long spines (center); and tiny spines (right) all overlying concentric layers of chitin.

Fig. 4. Hydra madagascarensis n.sp., cultivée en laboratoire et nourrie avec trois artemia par jour. A : polype mâle semblable en apparence aux polypes asexués ; sa colonne mesure $6,5 \mathrm{~mm}$ de long. B : polype hermaphrodite, $7,1 \mathrm{~mm}$ de long. C-F : nématocyste sténotèle, isorhize holotriche, isorhize atriche et desmonème. (G) trois types de décoration des embryothèques : ampoules chitineuses (à gauche); épines relativement longues (au centre); et petites épines (à droite). Ces ornements reposent sur la surface extérieure des lamelles concentriques de chitine.

\subsubsection{Behavior}

These polyps are mobile and phototactic in the laboratory and generally crowd into small areas within the culture dishes.

\subsubsection{Distribution}

H. madagascarensis is distributed widely through the central highlands of Madagascar (Fig. 3B) but is encountered less frequently than is $H$. viridissima. It is found in ponds, lakes and streams. It was not found in the absence of the green hydra, and the two species were sometimes side-by-side on a single leaf or stick.

\subsubsection{Differential diagnosis}

This hydra is distinguishable from other hydra on the .basis of the nematocysts, particularly of the holotrichous isorhizas. All hydra from outside Africa that have broad holotrichous isorhizas (that is, the braueri group of species) have regularly and tightly coiled tu- bules, whereas in the present species the coiling is loose and variable. The spined embryotheca also distinguishes $H$. madagascarensis from species of the braueri group except for $H$. americana Hyman 1929, which differs in the relative sizes of the four types of nematocysts and length of embryothecal spines. Three species of African hydra have swollen holotrichous isorhizas and are similar to $H$. madagascarensis. Both $H$. intabe Ewer 1948 and $H$. umfala Ewer 1948 differ in the sizes of the isorhizas. The simultaneous formation of tentacles on buds also distinguishes $H$. madagascarensis from $H$. umfala. The holotrichous isorhizas of $H$. mariana Cox and Young 1973 are quite different in coiling and shape from those of $H$. madagascarensis and the latter has considerably larger stenoteles. However all of these species appear to be closely related to one another. 

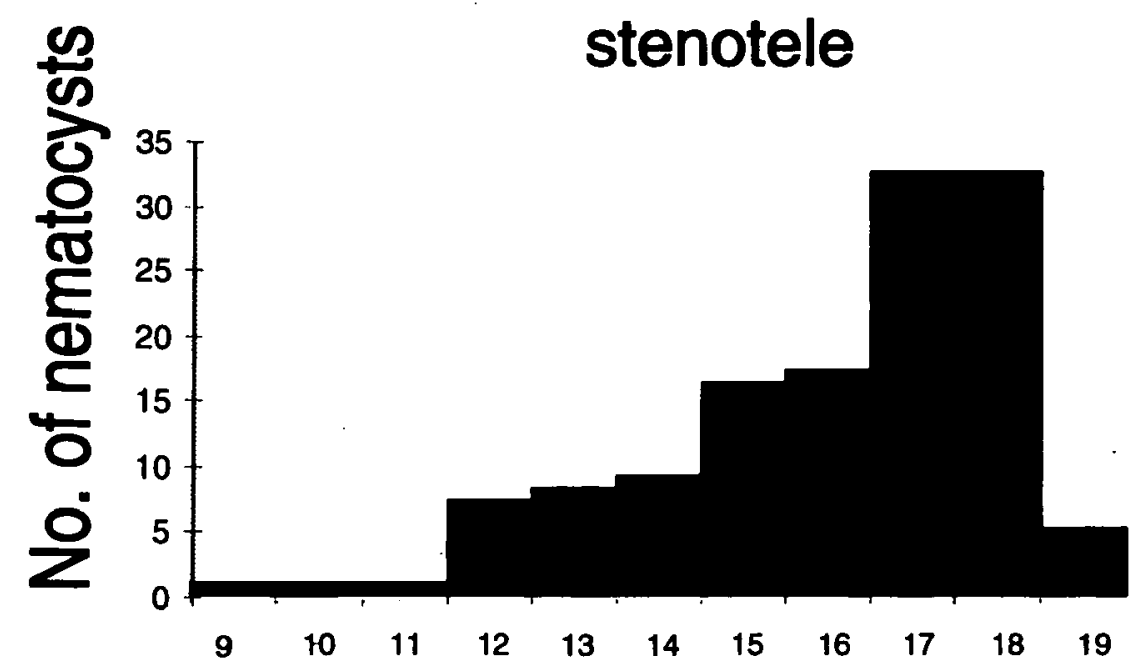

holotrich

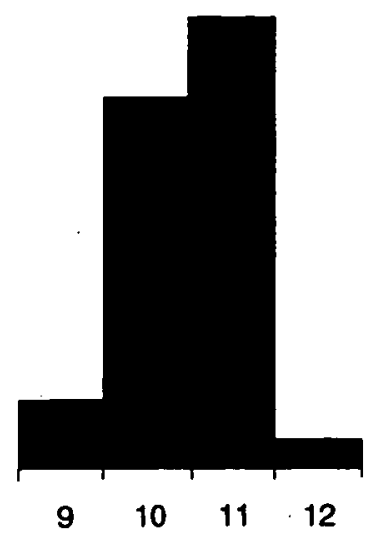

atrich

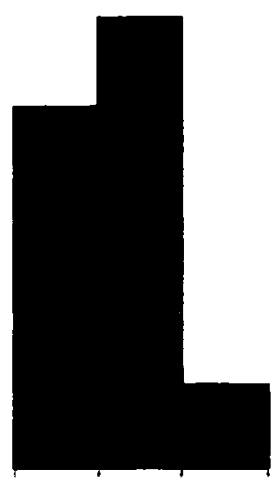

$\begin{array}{lll}7 & 8 & 9\end{array}$ desmo

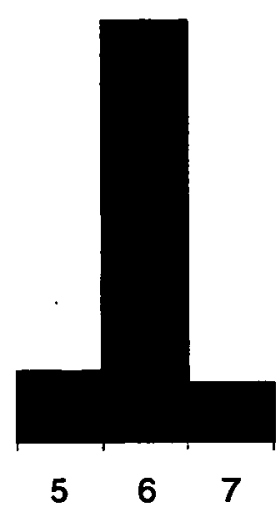

\section{Length of nematocyst $(\mu)$}

Fig. 5. Lengths of nematocysts in tentacles of Hydra madagascarensis n.sp. Means and standard deviations of the four types are, respectively : 16.1 $\pm 2.1 \mu \mathrm{m}(\mathrm{n}=97) ; 10.5 \pm 0.7 \mu \mathrm{m}(\mathrm{n}=68) ; 7.7 \pm 0.6 \mu \mathrm{m}(\mathrm{n}=67) ;$ and $6.0 \pm 0.5 \mu \mathrm{m}(\mathrm{n}=41)$. Measurements were made to the nearest micrometer.

Fig. 5. Longueur des nématocystes des tentacules de Hydra madagascarensis n.sp. Les moyennes et standards de déviation des quatre types sont respectivement : $16.1 \pm 2.1 \mu \mathrm{m}(\mathrm{n}=97) ; 10.5 \pm 0.7 \mu \mathrm{m}(\mathrm{n}=68) ; 7.7 \pm 0.6 \mu \mathrm{m}(\mathrm{n}=67) ;$ and $6.0 \pm 0.5 \mu \mathrm{m}(\mathrm{n}=41)$. Les mesures sont arrondies au plus proche micromètre.

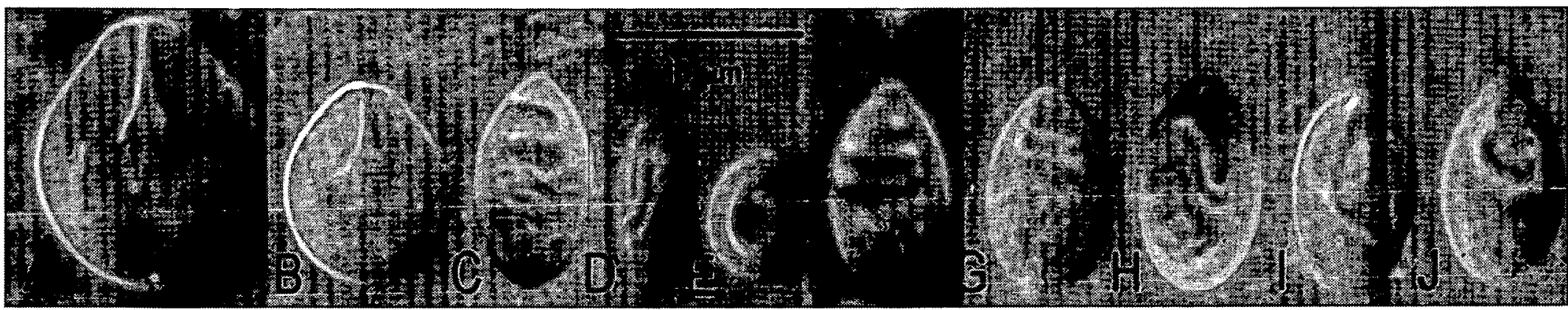

Fig. 6. Nematocysts of Hydra madagascarensis n.sp. A-E : normal stenoteles (A-B), and holotrichous isorhiza, atrichous isorhiza and desmoneme nematocysts (C-E). F-J : common variants of the holotrichous isorhiza.

Fig. 6. Nématocystes de Hydra madagascarensis n. sp. A-E : Nématocystes sténotèle normaux (A-B), isorhize holotriche, isorhize atriche et desmonème. F-J : Variations communes des isorhizes holotriches.

\subsubsection{Systematic position}

$H$. madagascarensis has characters of two of the groups of hydra as outlined by Campbell (1987) : its spined embryotheca is indicative of the vulgaris group, but its hermaphroditism suggests the braueri group. The diagnostic holotrichous isorhiza itself has characteristics typical of both groups : the general configuration of the tubule fits the vulgaris group and the swollen shape of the capsule suggests the braueri group.

\subsubsection{Type locality}

The type locality is $33 \mathrm{~km} \mathrm{~S}$ Ambositra along route 7 , beside the west side of road, in a mountain lake about $20 \mathrm{~m}$ across with a cold spring-fed stream running through it. Hydra were found on the undersides of
Nymphaea pads, and were scarce and spotty in distribution.

Other localities (Fig. 3B) : $33 \mathrm{~km} \mathrm{~S}$ Ambositra, across the road from the type locality in a rice paddy at the base of a woodland reservoir ; $30 \mathrm{~km} \mathrm{~N}$. Ambositra in a rice paddy about $100 \mathrm{~m} \mathrm{~S}$ of Ilaka $; 17 \mathrm{~km} \mathrm{~N} \mathrm{Am-}$ bositra in a rice paddy ; $10 \mathrm{~km} \mathrm{~W}$ Ambatolampy (ca $40 \mathrm{~km} \mathrm{~S}$ Antananarivo) in Lac Froid in Manjakalompo Forest/Pisciculture Reserve, under rocks in the exit stream about $5 \mathrm{~m}$ below the lake; $75 \mathrm{~km} \mathrm{~S}$ Antsiranana at the exit stream at the SE end of Lac Antanavo (also called Lac Sacré) ; $9 \mathrm{~km} \mathrm{~S} \mathrm{Ambahomahasoa} \mathrm{in} \mathrm{a}$ woodland lake ; and $90 \mathrm{~km} \mathrm{NW} \mathrm{Antananarivo} \mathrm{in} \mathrm{the}$ reservoir on the SW side of road. 


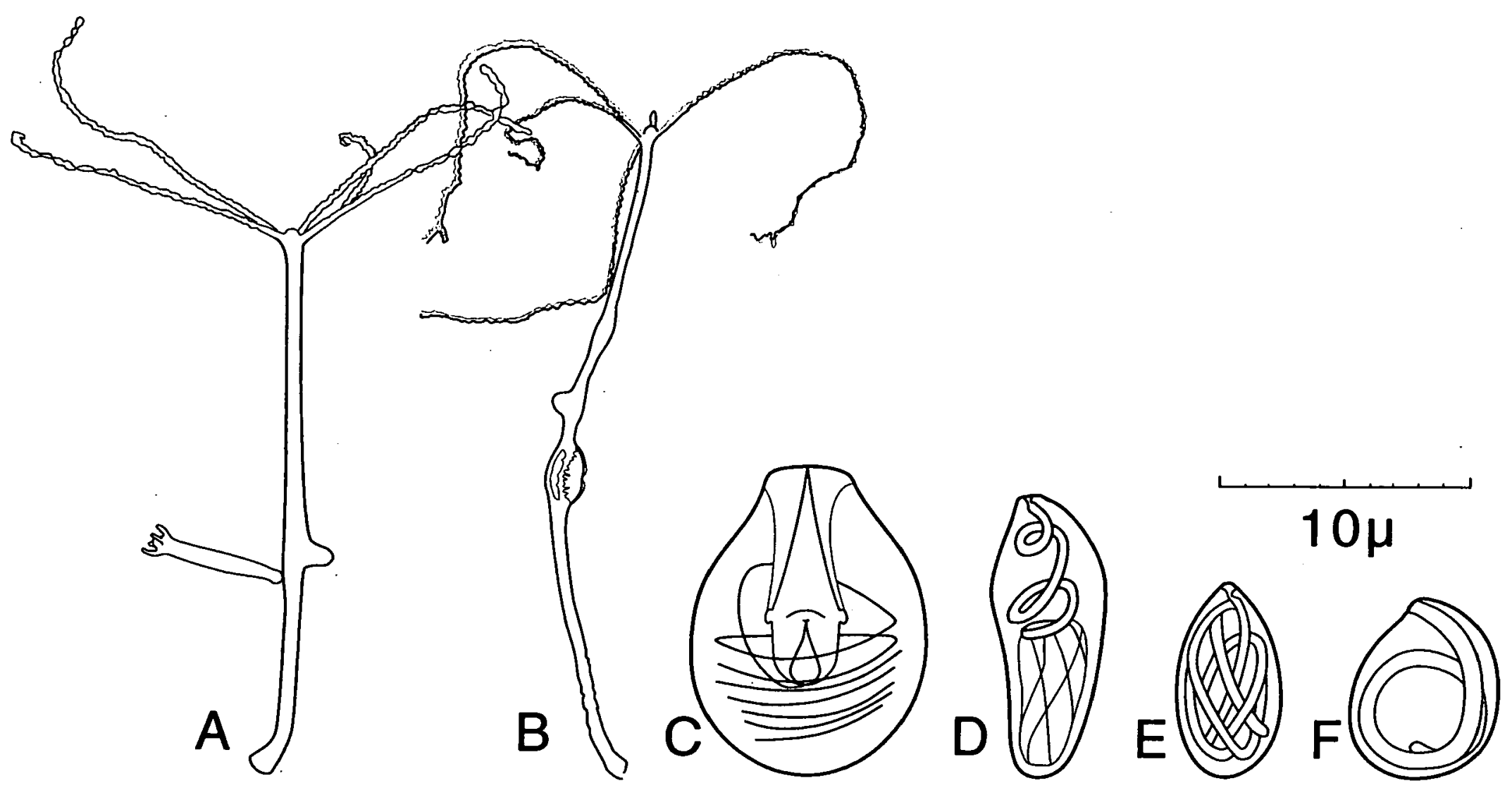

Fig. 7. Hydra sp. A : male. B : female. C-F : stenotele, holotrichous isorhiza, atrichous isorhiza and desmoneme nematocysts. Fig. 7. Hydra sp. A : mâle. B : femelle. C-F : nématocyste sténotèle, isorhize holotriche, isorhize atriche et desmonème.

Type specimens are deposited as catalog \# 10007477 in the United States National Museum of Natural History, Washington, DC.

\subsection{Hydra sp.}

One collection was made of another brown hydra (Fig. 7). Under laboratory culture with a feeding regimen of two artemia per day the column is slender and 3-5 $\mathrm{mm}$ long in relaxed hydra. These hydra have short, delicate tentacles, one-third to one-half the length of the column (Fig. 7). When the hydra are grown on two or fewer artemia each day they produce buds at a rate of one bud per six days and rarely have more than two buds. Buds are opposite one another on the column. When fed more than two artemia per day the hydra often enters depression. The stalk is not distinct from the higher column. Buds acquire tentacles simultaneously. Occasional polyps have formed a single ovary each at the level where a bud is expected and these polyps become long (10-11 mm) and slender. Other polyps have formed two or three testes, with the column remaining unchanged in length. Thus this species is dioecious. However the culture studied most carefully in the laboratory was an asexual clone started from a single collected polyp. Thus reversal of sexes occurs.
The nematocysts are shown in Fig. 7C-F. Their sizes (in $\mu$ ) are : stenotele, $11.8 \pm 0.8(n=44)$; holotrichous isorhiza, $10.6 \pm 0.6(\mathrm{n}=17)$; atrichous isorhiza, $8.4 \pm 0.5(n=22)$; and desmoneme, $6.2 \pm 0.4(n=37)$. The most unusual aspect of the nematocysts is the bent, spindle shape of the holotrichous isorhiza. The stenotele is smaller than in almost all of the non-green hydra.

Since their sexual characters are not known completely, these hydra cannot be adequately described or assigned to a species. They appear to fit well into the vulgaris group of species in the following respects : stenoteles are narrower than in the braueri group ; the holotrichous isorhiza is narrow and bent in the middle ; sexes develop separately and testes are distributed along the length of the column. However their stenotele nematocysts are smaller than most hydra of the vulgaris group.

The single site where these hydra were found (Fig. $3 \mathrm{C}$ ) is $40 \mathrm{~km} \mathrm{~W}$ Ambalavao along route 7 in the large Lomandao River midway between the two dams, at a depth of 5 feet on submerged branches near the muddy bottom.

A specimen is deposited as catalog \# 100080 in the United States National Museum of Natural History, Washington, DC. 


\section{Distribution and abundance of hydra in Madagascar}

As Figs. 3A-C show, hydra are distributed widely in Madagascar, including most of the major zoogeographic regions : northern and eastern tropical areas ; southwestern deserts ; and central highlands. They are found in small and large bodies of water, and in stagnant, slowly and rapidly moving waters. Although widely distributed, hydra are absent from most bodies of water and as a result they appear to be uncommon and are difficult to find. Most water in Madagascar is extensively modified, directly or indirectly, by man and evidently not suitable for hydra. Laundry activities are widespread in Madagascar waters and noticeably associated with the lack of hydra. Much water is discolored and ill-smelling and in these circumstances hydra were usually not found in it. In addition, many streams and rivers are opaque with eroded soil and hydra were not found in these waters.

The most consistent type of water in which hydra could be found is the «sacred lake," water from which, for one reason or another, is excluded from most human activities. These waters are usually cleaner than others. Hydra were also frequently found in rice paddies that were permanent enough to have aquatic plants growing in them.

\section{Discussion}

\subsection{Relations of African hydra}

There are five previous reports of hydra from Africa, each one assigning the hydra to a separate species. Two of these studies dealt with preserved hydra : Hydra ethiopiae Hickson 1930 is described too incompletely for an understanding of its relations with other hydra ; and hydra collected in central Africa were provisionally ascribed to $H$. vulgaris (Semal-van Gansen, 1953 ; Bouillon \& Semal-van Gansen, 1956) but the fixed state of the nematocysts and the lack of reproductive structures prevent further systematic analysis of them.

The three remaining African species are marked by broad holotrichous isorhizas and are hermaphroditic, both characters of $H$. madagascarensis. Cox \& Young (1973) present excellent comparative descriptions of four populations of $H$. mariana from Kenya, showing it to be quite a variable species. Ewer (1948) described $H$. intaba and $H$. umfula from South Africa. These three species, and $H$. madagascarensis, appear intermediate between the vulgaris and braueri groups of boreal hydra. They have a broad holotrichous isorhiza suggestive of the braueri group but the internal coiling is more typical of the vulgaris group. They exhibit her- maphroditism typical of the braueri group but the spherical and spined embryotheca resembles that of the vulgaris group.

This is the first description of green hydra from Africa, and the animal closely resembles descriptions of the European $H$. viridissima (Holstein 1995).

\subsection{Zoogeography of Malagassy hydra}

Hydra were located in 37 of the 106 sites examined. This probably overstates the frequency of occurrence of hydra, however, because water that was obviously polluted was often not examined in this study. Other than pollution, there was no obvious geographic or ecological distinction between the sites where hydra were found or not found. Hydra were found on the Eastern escarpment, in the Central highlands, on the Western coastal plain and in the Northern plains and mountains.

Apparently the main types of hydra are very old. The distinction between green and brown hydra is present in Madagascar, so this distinction must have existed before the breakup of the continents. The fact that $H$. viridissima is present both in Madagascar and in other parts of the world indicates that this species itself is extremely old and stable.

The oligactis group, one of the four groups of northern continental species of hydra, appears to be absent from Madagascar. The most widespread species of this group, $H$. oligactis Pallas 1766, is abundant and conspicuous in boreal waters. It may have evolved recently in the northern land masses after the separation of Madagascar. Or it may be an old boreal species that has been prevented, perhaps by temperature, from spreading into the southern hemisphere. It is frequently cited as a cold-water species. While there are claims that $\boldsymbol{H}$. oligactis is found both in Africa (Schmarda 1854) and in Australia and New Zealand (Bale 1884 : 187-188; von Lendenfeld 1885 : 627), these reports preceded a good understanding of the distinctions between species. Hence it is possible that the species of the oligactis group are restricted to the northern hemisphere.

These conclusions about the zoogeography of hydra are based on the assumption that the hydra described in this report are native to Madagascar. It is hard to imagine how hydra could be transported so far across salt water, and the conventional view that hydra are absent from oceanic islands supports this view (Hickson 1930 , Mumford 1940b, hydra have been found in Hawaii, Mumford 1940a, but it is likely these were introduced by man). It seems possible that exotic hydra might be transported easily with aquatic plants and 
animals of trade. Such introductions are evident in other fauna (e.g. Mills 1995) and Madagascar has its full share of introduced, non-indigenous species. However the Malagassy hydra appear to be native for the following two reasons. First, $H$. madagascarensis and the unnamed hydra are distinct from other described hydra, although admittedly the hydra of Africa are poorly studied and there is similarity between $H$. madagascarensis and other known African hydra. Second, the Malagassy hydra are found in sacred lakes and other outlying lakes where there is relatively little human activity. One of the lakes where both $H$. viridissima and $H$. madagascarensis were found, Lake Tritri$v a$, is a crater lake with restricted fauna and flora and with such poor access that it is unlikely that foreign animals would have been introduced into it. Any contamination of the Malagassy fauna by foreign hydra will be detectable by nucleic acid sequence analysis.

\section{Acknowledgments}

Paul C. Campbell and Mr. Andrianahimanana Cyprien Ramboatahina provided crucial help in both the logistics and the fieldwork. Dr. Césaire Rabenoro, President of the Académie Nationale, offered encouragement and hospitality. Ana Soko helped with the culture and analysis. Thomas Holstein provided comments on the manuscript. France Campbell aided in all phases of this work.

\section{References}

Bale W.M. 1884. - Catalogue of the Australian Hydroid Zoophytes. Sub-order III. - Eleutheroblastea. Thomas Richards (Australian Museum), Sydney : $188 \mathrm{p}$.

Bouillon J. \& Semal-van Gansen P. 1956. - Sur quelques hydres africaines. Rev. Zool. Bot. Afr., 54 : 202-208.

Campbell R.D. 1987.- A new species of Hydra (Cnidaria : Hydrozoa) from North America with comments on species clusters within the genus. Zool. J. Linnean Soc., 91 : 253-263.
Cox N. \& Young J.O. 1973.- - A new species of Hydra (Coelenterata) from Kenya, East Africa. Zoology (Lond.), 170 : 441-449.

Ewer R.F. 1948. - A Review of the Hydridae and Two New Species of Hydra from Natal. Proc. Zool. Soc. Lond., $118: 226-244$.

Forrest H. 1959.- Taxonomic studies on the hydras of North America VII. Description of Chlorohydra hadleyi, new species, with a key to the North American species of hydra. Am. Mid. Nat., 62 : 440-448.

Grayson R.F. 1971.- The freshwaters hydras of Europe 1. A review of the European species. Arch. Hydrobiol., $68: 436-449$.

Hickson S.J. 1930.- Report on the Hydras collected during Dr. Hugh Scott's and Mr. Omer-Cooper's expedition to Abyssinia. (H. ethiopiae sp n.). Proc. zool. Soc. Lond., 1930 : 63-64.

Holstein T. 1995.- Cnidaria : Hydrozoa. In : J.R. Schwoerbel and P. Zwick (eds.), Süsswasserfauna von Mitteleuropa 1.2. Gustav Fischer, Stuttgart : $110 \mathrm{p}$.

Mills C.E. 1995.- Invertebrate introductions in marine habitats : two species of hydromedusae (Cnidaria) native to the Black Sea, Maeotias inexspectata and Blackfordia virginica, invade San Francisco Bay. Mar. Biol., 122 : 279-288.

Mumford E.P. 1940a.- The present status of studies of faunal distribution with reference to oceanic islands. Proceedings of the 6 th Pacific Science Congress (Berkeley, California), 4 : 241-248.

Mumford E.P. 1940b. - The present status of knowledge of Polynesian fresh-water faunas. Proceedings of the 6th Pacific Science Congress (Berkeley, California), $4: 249-251$.

Paulian R. 1961.- La Zoogéographie de Madagascar et des Iles voisines. Faune de Madagascar, $13: 1-484$.

Schmarda L.K. 1854.-Zur Naturgeschichte Aegyptens. Dshr. K. Akad. Wiss. Math.-Nat. Kl., $7:$ 1-28.

Schulze P. 1917. - Neue Beiträge zu einer Monographie der Gattung Hydra. Arch. Biontol., $4: 29-119$.

Schulze P. 1927.- Zur Kenntnis und geographischen Verbreitung der Süsswasserpolypen. Zool. Anz., 74 : 129-140.

Semal-van Gansen P. 1953. - Une hydre d'eau douce au Congo Belge. Ann. Soc. roy. zool. Belg., 84 : 267-270.

Semal-van Gansen P. 1954. - La structure des nématocystes de l'Hydre d'eau douce. Bull. Cl. Sci. Acad. roy. Belg. $5^{e}$ Sér., 40 : 269-287.

Thorington G., Berger B. \& Margulis L. 1979.— Transmission of symbionts through the sexual cycle of Hydra viridis. I. Observations on living organisms. Trans. Am. micr. Soc., $98: 401-413$.

von Lendenfeld R. 1885. - Über Coelenteraten der Südsee. Z. Wiss. Zool., 41 : 616-682. 